\title{
MEKANISME IMPLEMENTASI SIDANG PENYELESAIAN SENGKETA INFORMASI PUBLIK (AJUDIKASI NON LITIGASI) DI KOMISI INFORMASI PROVINSI KALIMANTAN SELATAN
}

\author{
Tamliha Harun \\ FIA, Universitas Achmad Yani Banjarmasin \\ Email: tamlihaharun@gmail.com
}

\begin{abstract}
The title of this research is: "Mechanism of Implementation of Public Information Dispute Settlement Session (Non-Litigation Adjudication) at Information Commission of South Kalimantan Province". This research was conducted with the intention to provide input to the Information Commission of South Kalimantan Province in an effort to improve its performance, especially in the implementation of public information dispute resolution session (non litigation adjudication). And also to inform the public, so all of them know and understand how the mechanism of public information dispute resolution session in Information Commission. This research is a descriptive research, with its data collection techniques : interview, observation, and documentation, then analyzed qualitatively. The result of the research shows that : The mechanism of implementation of public information dispute resolution in Information Commission of South Kalimantan Province has been implemented in accordance with the provisions regulated by Undang-undang Nomor 14 Tahun 2008 About KIP and PERKI Nomor 1 Tahun 2013 About Public Information Dispute Procedure. In order for the implementation of public information dispute resolution hearing in the Information Commission to work better and professional, it is recommended that the commissioners need to follow the education/ non-litigation adjudication mediation training and secretariat follow the education/ training of registrant, and supported by representative facilities and infrastructure in the implementation of information dispute resolution session.
\end{abstract}

Keywords: mechanism, non-litigation adjudication, information commission

\section{PENDAHULUAN}

Hak untuk memperoleh informasi merupakan hak asasi manusia (HAM) dan keterbukaan informasi publik merupakan salah satu ciri penting dari negara demokratis yang menjunjung tinggi kedaulatan rakyat, untuk mewujudkan penyelenggaraan pemerintahan negara yang baik (good governance).

Untuk menjamin hak asasi manusia, khususnya warga negara Indonesia dalam memperoleh informasi, maka Undang-Undang Dasar 1945 pasal $28 \mathrm{~F}$ telah menggariskan bahwa : "Setiap orang berhak untuk berkomunikasi dan memperoleh informasi untuk mengembangkan pribadi dan lingkungan sosialnya, serta berhak untuk mencari, memperoleh, memiliki, menyimpan, mengolah, dan menyampaikan informasi dengan menggunakan segala jenis saluran yang tersedia".

Sebagai implementasi pasal 28 F UUD 1945 dan untuk memberikan jaminan terhadap semua orang dalam memperoleh informasi, perlu dibentuk undang-undang yang mengatur tentang keterbukaan informasi publik, karena hak untuk memperoleh informasi merupakan hak asasi manusia yang merupakan wujud dari kehidupan berbangsa dan bernegara yang demokratis.

Salah satu elemen penting dalam mewujudkan penyelenggaraan negara yang demokratis adalah prinsip transparansi atau keterbukaan informasi. Penyelenggaraan negara yang terbuka, berarti rakyat mempunyai hak untuk memperoleh informasi sesuai peraturan perundang-undangan. Hak atas informasi 
menjadi sangat penting, karena makin terbuka penyelenggaraan negara untuk diawasi publik, maka penyelenggaraan negara tersebut semakin dapat dipertanggungjawabkan. Hak setiap orang untuk memperoleh informasi juga relevan untuk meningkatkan kualitas pelibatan masyarakat dalam proses pengambilan keputusan publik. Partisipasi atau pelibatan masyarakat tidak banyak berarti tanpa jaminan keterbukaan informasi publik.

Lahirnya Undang-Undang Nomor 14 Tahun 2008 tentang Keterbukaan Informasi Publik (KIP) mempunyai makna sangat penting sebagai landasan hukum yang berkaitan dengan : (1) Hak setiap orang untuk memperoleh informasi ; (2) Kewajiban badan publik menyediakan dan melayani permintaan informasi secara cepat, tepat waktu, biaya ringan, dan dengan cara yang sederhana ; (3) Pengecualian informasi bersifat ketat dan terbatas ; (4) Kewajiban badan publik untuk membenahi sistem pengelolaan informasi dan dokumentasi.

Dalam undang-undang keterbukaan informasi publik tersebut dijelaskan, antara lain, bahwa : Informasi Publik adalah informasi yang dihasilkan, disimpan, dikelola, dikirim, dan/atau diterima oleh suatu badan publik yang berkaitan dengan penyelenggara negara dan penyelenggaraan negara dan/atau penyelenggara dan penyelenggaraan badan publik lainnya yang sesuai dengan undang-undang ini, serta informasi lain yang berkaitan dengan kepentingan publik. Sedangkan Badan Publik adalah lembaga eksekutif, legislatif, yudikatif, dan badan lain yang fungsi dan tugas pokoknya berkaitan dengan penyelenggaraan negara, yang sebagian atau seluruh dananya bersumber dari Anggaran Pendapatan dan Belanja Negara dan/atau Anggaran Pendapatan dan Belanja Daerah, atau organisasi non pemerintah sepanjang sebagian atau seluruh dananya bersumber dari APBN dan/atau APBD, sumbangan Masyarakat, dan/atau luar negeri.

Dengan adanya undang-undang keterbukaan informasi publik, diharapkan dapat mendorong badan publik yang selama ini cenderung sangat tertutup dalam hal informasi, akan berubah menjadi lebih terbuka dan bertanggungjawab dalam memberikan pelayanan terbaik kepada rakyat. Mewujudkan badan publik yang terbuka dan bertanggungjawab dalam segala aktivitasnya, merupakan salah satu upaya strategis untuk mencegah praktik korupsi, kolusi, dan nepotisme (KKN), yang pada giliranya akan dapat mewujudkan pemerintahan yang baik (good governance).

Bagi publik (masyarakat) kehadiran undang-undang keterbukaan informasi publik merupakan bentuk pengakuan hak publik atas informasi dan bagaimana hak tersebut seharusnya dipenuhi dan dilindungi. Bagi badan publik keberadaan UU KIP merupakan pedoman hukum untuk memenuhi dan melindungi hak atas informasi bagi publik. Pedoman hukum tersebut untuk menghindari terjadinya pelanggaran hak publik atas informasi, sekaligus jaminan agar keterbukaan informasi tidak merugikan kepentingan setiap orang (publik) dan kepentingan badan publik atau negara, karena dilindungi oleh undang-undang tersebut.

Hal penting lainnya yang diatur dalam UU KIP tersebut adalah perintah dibentuknya Komisi Informasi Pusat yang berkedudukan di ibu kota negara, Komisi Informasi Provinsi di ibu kota provinsi, dan jika dibutuhkan dapat dibentuk Komisi Informasi Kabupaten/Kota di ibu kota Kabupaten/Kota. Komisi informasi merupakan lembaga mandiri yang berfungsi menjalankan undang-undang keterbukaan informasi publik dan peraturan pelaksanaannya, menetapkan petunjuk teknis standar layanan informasi publik dan menyelesaikan sengketa informasi publik melalui mediasi dan/atau ajudikasi nonlitigasi.

Komisi Informasi Kalimantan Selatan Periode Tahun 2014 - 2018, telah terbentuk pada tanggal 4 Agustus 2014 dengan Surat Keputusan Gubernur Kalimantan Selatan Nomor 188.44/0391/KUM/2014, dan pelantikan kelima komisionernya dilakukan oleh Gubernur di Graha Abdi Persada Pemerintah Propinsi Kalimantan di Banjarmasin pada tanggal 26 Agustus 2014. Menurut Evy Trisulo, komisioner Komisi Informasi Pusat dalam sambutannya dalam acara pelantikan tersebut, mengatakan bahwa Komisi Informasi Provinsi Kalimantan Selatan merupakan Komisi Informasi Provinsi urutan yang ke 26 dalam 
pembentukannya se Indonesia sejak dimulai berlakunya UU KIP pada 30 April 2010.

Apabila dilihat dari segi keberadaannya, maka Komisi Informasi Provinsi Kalimantan Selatan sudah berusia kurang lebih 3 (tiga) tahun, suatu usia yang relatif muda, namun sudah cukup waktu untuk menata dan membenahi dirinya dalam upaya konsolidasi kelembagaan baik secara internal maupun eksternal. Itu artinya, Komisi Informasi Provinsi Kalimantan Selatan baik secara organisasi, sumber daya manusia, anggaran, maupun sarana dan prasarananya seharusnya sudah siap, sehingga dapat melaksanakan fungsi, tugas, wewenang dan kewajibannya sesuai dengan ketentuan yang telah diatur undang-undang.

Sesuai dengan Undang-Undang Nomor 14 Tahun 2008 tentang Keterbukaan Informasi Publik, pasal 26 ayat (3) disebutkan bahwa "Komisi Informasi provinsi dan/atau Komisi Informasi kabupaten/kota bertugas menerima, memeriksa, dan memutus sengketa informasi publik di daerah melalui mediasi dan/atau ajudikasi non litigasi.

Sehubungan dengan tugas pokok yang sudah digariskan oleh undang-undang tersebut, maka rumusan masalah dalam penelitian ini adalah Bagaimana Mekanisme Implementasi Sidang Penyelesaian Sengketa Informasi Publik (Ajudikasi Nonlitigasi) di Komisi Informasi Provinsi Kalimantan selatan ?

Undang-Undang Nomor 14 Tahun 2008 tentang Keterbukaan Informasi Publik, Peraturan Pemerintah Nomor 61 Tahun 2010 tentang Pelaksanaan Undang-Undang Nomor 14 Tahun 2008 tentang KIP, Peraturan Komisi Informasi (PERKI) Nomor 1 Tahun 2013 tentang Prosedur Penyelesaian Sengketa Informasi (PPSI) merupakan bentuk/wujud kebijakan publik di bidang keterbukaan informasi publik. Setiap kebijakan publik yang sudah dirumuskan, kemudian disahkan oleh lembaga yang berwenang sudah seharusnya diimplementasikan agar tujuan yang ingin dicapai oleh kebijakan tersebut dapat terwujud. Tanpa implementasi, sebuah kebijakan publik, sebaik apapun rumusannya, tidak akan ada manfaatnya bagi publik.

Di dalam Peraturan Menteri Negara PAN
Nomor : PER/04/M.PAN/4/2007, tentang
Pedoman Umum Formulasi, Implementasi, Evaluasi Kerja, dan Revisi Kebijakan Publik di Lingkungan Lembaga Pemerintah Pusat dan Daerah, ditegaskan bahwa : "Kebijakan publik adalah keputusan yang dibuat oleh pemerintah atau lembaga pemerintahan untuk mengatasi permasalahan tertentu untuk kegiatan tertentu atau untuk mencapai tujuan yang berkenaan dengan kepentingan dan manfaat orang banyak" (Rawita, 2010).

Menurut Kamus Webster (dalam Abdul Wahab, 1997) merumuskan secara pendek bahwa :

to implement (mengimplementasikan) berarti to provide the means carrying out (menyediakan sarana untuk melaksanakan sesuatu), to give practical effect to (menimbulkan dampak/akibat sesuatu). Kalau pandangan ini kita ikuti, maka implementasi kebijakan dapat dipandang sebagai proses melaksanakan keputusan kebijakan (biasanya dalam bentuk undang-undang, peraturan pemerintah, keputusan presiden, perintah eksekutif, atau dekrit presiden). Van Matter dan Van Horn dalam Abdul Wahab (1997) merumuskan bahwa "Implementasi kebijakan sebagai tindakan-tindakan yang dilakukan baik oleh individu/pejabat-pejabat atau kelompok-kelompok pemerintah atau swasta yang diarahkan pada tercapainya tujuantujuan yang telah digariskan dalam keputusan kebijakan".

Selajutnya Jones (dalam Ali Imron, 1996) menyatakan bahwa : Implementasi kebijakan adalah sebagai konsep yang dinamis, memerlukan usaha-usaha untuk mencari apa yang akan dan dapat dilaksanakan. Implementasi akhirnya dipahami sebagai pengaturan aktivitas yang mengarah pada penempatan program ke dalam suatu dampak. Tiga aktivitas utama dalam implementasi adalah interpretasi, organisasi, dan aplikasi. Interpretasi adalah aktivitas menterjemahkan makna program ke dalam pengaturan yang dapat diterima dan dijalankan. Organisasi adalah unit atau wadah yang dipergunakan untuk menempatkan program. Sementara aplikasi adalah konsekuensi berupa pemenuhan perlengkapan serta biaya yang dibutuhkan.

Lebih tegas dan sederhana di dalam Peraturan Menteri Negara Pendayagunaan 
Aparatur Negara Nomor : PER/04/M.PAN/4/2007 tentang Pedoman Umum Formulasi, Implementasi, dan Revisi Kebijakan Publik di Lingkungan Pemerintah Pusat dan Daerah, dirumuskan bahwa "Implementasi Kebijakan publik adalah suatu kegiatan atau proses pelaksanaan atau penerapan kebijakan publik yang telah ditetapkan".

Dari beberapa pendapat di atas dapat disimpulkan bahwa implementasi kebijakan publik adalah proses kegiatan yang dilakukan baik oleh aktor formal (pemerintah) maupun aktor non formal (non pemerintah) untuk melaksanakan dan merealisasikan programprogram kebijakan yang telah disahkan secara nyata agar tujuan atau dampak yang diharapkan dapat tercapai.

Implementasi kebijakan merupakan tahapan yang sangat penting dari seluruh proses kebijakan. Bahkan Udoji (dalam Abdul Wahab, 1997) dengan tegas mengatakan bahwa "Pelaksanaan kebijakan jauh lebih penting dari pada pembuatan kebijakan. Kebijakan-kebijakan akan hanya sekedar berupa impian-impian atau rencana bagus yang tersimpan rapi dalam arsip kalau tidak diimplementasikan".

Selanjutnya, Ali Imron (1996) mengatakan bahwa : Tolok ukur keberhasilan sebuah kebijakan ada pada implementasinya. Sebaik apapun rumusan sebuah kebijakan jika tidak diimplementasikan akan tidak ada dirasakan gunanya. Sebaliknya sesederhana apapun rumusan sebuah kebijakan, jika sudah diimplementasikan, akan lebih berguna, apapun dan seberapapun hasilnya.

Implementasi kebijakan harus dilakukan, karena problema-problema yang dirumuskan dalam sebuah kebijakan menuntut pemecahan melalui tindakan nyata, dan tidak sekedar pemecahan secara konseptual. Jika secara konseptual, rumusan pemecahan problema tersebut sudah dilakukan pada saat formulasi kebijakan, maka ia menuntut dipecahkan senyatanya melalui implementasi.

Akan diketahui secara jelas melalui implementasi, apakah suatu rumusan alternatif pemecahan masalah tertentu, betul-betul sesuai dengan masalahnya atau tidak. Akan diketahui apakah setelah diterapkan alternatif pemecahan masalah yang telah dirumuskan, menimbulkan masalah baru atau tidak. Pendek kata, implementasi menjadi tolok ukur tepat-tidaknya, akurat-tidaknya, relevan-tidaknya, dan realististidaknya suatu rumusan kebijakan yang sudah ditetapkan.

Secara normatif, mekanisme memperoleh informasi telah diatur dalam Undang-Undang Nomor 14 Tahun 2008 tentang Keterbukaan informasi publik, sbb :

- Pasal 21 : Mekanisme untuk memperoleh informasi publik berdasarkan pada prinsip cepat, tepat waktu, dan biaya ringan.

- Pasal 22 ayat (1) : Setiap pemohon informasi publik dapat mengajukan permintaan untuk memperoleh informasi publik kepada Badan Publik terkait secara tertulis atau tidak tertulis.

- Pasal 22 ayat (7) : Paling lambat 10 (sepuluh) hari kerja sejak diterimanya permintaan, Badan Publik yang bersangkutan wajib menyampaikan pemberitahuan tertulis yang berisikan :

a. Informasi yang diminta berada di bawah penguasaannya ataupun tidak ;

b. Badan Publik wajib memberitahukan Badan Publik yang yang menguasai informasi yang diminta apabila informasi yang diminta tidak berada di bawah penguasaannya dan Badan Publik yang menerima permintaan mengetahui keberadaan informasi yang diminta ;

c. Penerimaan atau penolakan permintaan informasi dengan alasan yang tercantum sebagaimana dimaksud dalam Pasal 17 ;

d. Dalam hal permintaan diterima seluruhnya atau sebagian dicantumkan materi informasi yang akan diberikan ;

e. Dalam hal suatu dokumen mengandung materi yang dikecualikan sebagaimana dimaksud dalam Pasal 17, maka informasi yang dikecualikan tersebut dapat dihitamkan dengan disertai alasan dan materinya ;

f. Alat penyampai dan format informasi yang akan diberikan; dan/atau

g. Biaya serta cara pembayaran untuk memperoleh informasi yang diminta ;

h. Badan Publik yang bersangkutan dapat memperpanjang waktu untuk mengirimkan pemberitahuan sebagaimana 
dimaksud pada ayat (7) paling lambat 7 (tujuh) hari kerja berikutnya dengan memberikan alasan secara tertulis.

- Pasal 35 :

(1) Setiap pemohon informasi publik dapat mengajukan keberatan secara tertulis kepada atasan pejabat pengelola informasi dan dokumentasi berdasarkan alasan berikut :

a. Penolakan atas permintaan informasi berdasarkan alasan pengecualian sebagaimana dimaksud dalam pasal 17 ;

b. Tidak disediakannya informasi berkala sebagaimana dimaksud dalam pasal 9 ;

c. Tidak ditanggapinya permintaan informasi ;

d. Permintaan informasi ditanggapi tidak sebagaimana yang diminta ;

e. Tidak dipenuhinya permintaan informasi ;

f. Pengenaan biaya yang tidak wajar ; dan/atau

g. Penyampaian informasi yang melebihi waktu yang diatur dalam undang-undang ini.

(2) Alasan sebagaimana dimaksud pada ayat (1) huruf b sampai dengan huruf g dapat diselesaikan secara musyawarah oleh kedua belah pihak.

- Pasal 36 :

(1) Keberatan diajukan oleh pemohon informasi publik dalam jangka waktu paling lambat 30 (tiga puluh) hari kerja setelah ditemukannya alasan sebagaimana dimaksud dalam pasal 35 ayat (1).

(2) Atasan pejabat sebagaimana dimaksud dalam pasal 35 ayat (1) memberikan tanggapan atas keberatan yang diajukan oleh pemohon informasi publik dalam jangka waktu paling lambat 30 (tiga puluh) hari kerja sejak diterimanya keberatan secara tertulis.

(3) Alasan tertulis disertakan bersama tanggapan apabila atasan pejabat sebagaimana dimaksud dalam pasal 35 ayat (1) menguatkan putusan yang ditetapkan oleh bawahannya.

- Pasal 37 :

(1) Upaya penyelesaian sengketa informasi publik diajukan kepada Komisi Informasi Pusat dan/atau Komisi Informasi Provinsi dan/atau Komisi Informasi Kabupaten/Kota sesuai dengan kewenangannya, apabila tanggapan atasan pejabat pengelola informasi dan dokumentasi dalam proses keberatan tidak memuaskan pemohon informasi publik.

(2) Upaya penyelesaian sengketa informasi publik diajukan dalam waktu paling lambat 14 (empat belas) hari kerja setelah diterimanya tanggapan tertulis dari atasan pejabat sebagaimana dimaksud dalam pasal 36 ayat $(2)$.

- Pasal 38 :

(1) Komisi Informasi Pusat dan/atau Komisi Informasi Provinsi dan/atau Komisi Informasi Kabupaten/Kota harus mulai mengupayakan penyelesaian sengketa informasi publik melalui mediasi dan/atau ajudikasi nonlitigasi paling lambat 14 (empat belas) hari kerja setelah menerima permohonan penyelesaian sengketa informasi publik.

(2) Proses penyelesaian sengketa sebagaimana dimaksud pada ayat (1) paling lambat dapat diselesaikan dalam waktu 100 (seratus) hari kerja.

- Pasal 39 : Putusan Komisi Informasi yang berasal dari kesepakatan melalui mediasi bersifat final dan mengikat.

- Pasal 40 :

(1) Penyelesaian sengketa melalui mediasi merupakan pilihan para pihak dan bersifat sukarela.

(2) Penyelesaian sengketa melalui mediasi hanya dapat dilakukan terhadap pokok perkara yang terdapat dalam pasal 35 ayat (1) huruf $b$, huruf $c$, huruf $d$, huruf e, huruf f, dan huruf $g$.

(3) Kesepakatan para pihak dalam proses mediasi dituangkan dalam bentuk putusan mediasi Komisi Informasi.

- Pasal 41 : Dalam proses mediasi anggota Komisi Informasi berperan sebagai mediator

- Pasal 42 : Penyelesaian sengketa informasi publik melalui ajudikasi nonlitigasi oleh Komisi Informasi hanya dapat ditempuh apabila upaya mediasi dinyatakan tidak berhasil secara tertulis oleh salah satu atau para pihak yang bersengketa, atau salah satu atau para pihak yang bersengketa menarik diri dari perundingan.

Tamliha Harun | Mekanisme Implementasi ..... 
- Pasal 43 :

(1) Sidang Komisi Informasi yang memeriksa dan memutus perkara paling sedikit 3 (tiga) orang anggota atau lebih dan harus berjumlah ganjil.

(2) Sidang Komisi Informasi bersifat terbuka untuk umum.

(3) Dalam hal pemeriksaan yang berkaitan dengan dokumen-dokumen yang termasuk dalam pengecualian sebagaimana dimaksud dalam pasal 17, maka sidang pemeriksaan perkara bersifat tertutup.

(4) Anggota Komisi Informasi wajib menjaga rahasia dokumen sebagaimana dimaksud pada ayat (3)

- Pasal 44 :

(1) Dalam hal Komisi informasi menerima permohonan penyelesaian sengketa informasi publik, Komisi Informasi memberikan salinan permohonan tersebut kepada pihak termohon.

(2) Pihak termohon sebagaimana dimaksud pada ayat (1) adalah pimpinan badan publik atau pejabat terkait yang ditunjuk yang didengar keterangannya dalam proses persidangan.

(3) Dalam hal pihak termohon sebagaimana dimaksud pada ayat (2), Komisi informasi dapat memutus untuk mendengar keterangan tersebut secara lisan ataupun tertulis.

(4) Pemohon informasi publik dan termohon dapat mewakilkan kepada wakilnya yang secara khusus dikuasakan untuk.

- Pasal 45 :

(1) Badan publik harus membuktikan halhal yang mendukung pendapatnya apabila menyatakan tidak dapat memberikan informasi dengan alasan sebagaimana dimaksud dalam pasal 17 dan pasal 35 ayat (1) huruf a.

(2) Badan publik harus menyampaikan alasan yang mendukung sikapnya apabila pemohon informasi publik mengajukan permohonan penyelesaian sengketa informasi publik sebagaimana diatur dalam pasal 35 ayat (1) huruf b samapai dengan huruf $g$.
- Pasal 46 :

(1) Putusan Komisi Informasi tentang pemberian atau penolakan akses terhadap seluruh atau sebagian informasi yang diminta berisikan salah satu perintah di bawah ini :

a. Membatalkan putusan atasan badan publik dan memutuskan untuk memberikan sebagian atau seluruh informasi yang diminta oleh pemohon informasi publik sesuai dengan putusan Komisi Informasi ; atau

b. Mengukuhkan putusan atasan pejabat pengelola informasi dan dokumentasi untuk tidak memberikan informasi yang diminta sebagian atau seluruhnya sebagaimana dimaksud dalam pasal 17.

(2) Putusan Komisi Informasi tentang pokok keberatan sebagaimana dimaksud dalam pasal 35 ayat (1) huruf b sampai dengan huruf $g$, berisikan salah satu perintah di bawah ini :

a. Memerintahkan pejabat pengelola informasi dan dokumentasi untuk menjalankan kewajibannya sebagaimana ditentukan dalam undang-undang ini ;

b. Memerintahkan badan publik untuk memenuhi kewajibannya dalam jangka waktu pemberian informasi sebagaimana diatur dalam undang-undang ini ; atau

c. Mengukuhkan pertimbangan atasan badan publik atau memutuskan mengenai biaya penelusuran dan/atau penggandaan informasi.

(3) Putusan Komisi Informasi diucapkan dalam sidang terbuka untuk umum, kecuali putusan yang menyangkut informasi yang dikecualikan.

(4) Komisi Informasi wajib memberikan salinan putusannya kepada para pihak yang bersengketa.

(5) Apabila ada anggota Komisi yang dalam memutus suatu perkara memiliki pendapat yang berbeda dari putusan yang diambil, pendapat anggota Komisi tersebut dilampirkan dalam putusan dan menjadi bagian tidak terpisahkan dari putusan tersebut.

Pasal 40 sampai dengan pasal 46 Undang-Undang Nomor 14 Tahun 2008 tentang 
Keterbukaan Informasi Publik merupakan hukum acara bagi Komisi informasi dalam melakukan mediasi dan/atau ajudikasi nonlitigasi sengketa informasi publik.

Sebagai penjabaran lebih rinci tentang tata cara/prosedur penyelesaian sengketa informasi publik, baik melalui jalur mediasi maupun jalur ajudikasi nonlitigasi telah ditetapkan Peraturan Komisi Informasi (PERKI) Nomor 1 Tahun 2013 tentang Prosedur Penyelesaian Sengketa Informasi Publik dan Peraturan Komisi Informasi (PERKI) Nomor 1 Tahun 2014 tentang Standar Layanan dan Prosedur Penyelesaian Sengketa Informasi Pemilihan Umum.

\section{METODE PENELITIAN}

Metode penelitian yang digunakan dalam penelitian ini adalah penelitian kepustakaan (library research) dan penelitian lapangan (field research). Sedangkan pendekatan yang digunakan dalam penelitian ini adalah pendekatan kualitatif.

Adapun tipe penelitian yang digunakan dalam penelitian ini adalah tipe penelitian deskriptif, yaitu penelitian yang berusaha mendeskripsikan suatu obyek penelitian secara obyektif, apa adanya sesuai dengan rumusan masalah dan tujuan penelitian yang sudah ditetapkan. Obyek penelitian ini adalah mekanisme implementasi sidang penyelesaian sengketa informasi publik (ajudikasi non litigasi).

Sumber data yang digali dalam penelitian ini adalah data primer dan data sekunder. Data primer diperoleh dari nara sumber (key informan), yaitu 5 (lima) orang komisioner dan 1 (satu) orang kepala sekretariat Komisi Informasi Provinsi Kalimantan Selatan. Sedangkan data sekunder diperoleh dari dokumen, catatan, laporan, arsip, dan lain-lain yang berhubungan dengan obyek penelitian.

Teknik pengumpulan data yang digunakan dalam penelitian ini adalah teknik wawancara, teknik observasi dan teknik dokumentasi. Teknik wawancara dan observasi digunakan untuk mengumpulkan data primer langsung kepada narasumber (key informan) mengenai bagaimana mekanisme implementasi sidang ajudikasi non litigasi. Sedangkan teknik dokumentasi digunakan untuk mengumpulkan data sekunder melalui dokumen, catatan, laporan, arsip, dan lain-lain terkait dengan implementasi sidang penyelesaian sengketa informasi (ajudikasi non litigasi) yang sudah dilaksanakan.

Untuk melakukan kajian atau analisis terhadap data peneltian yang diperoleh, digunakan analisis data kualitatif, yaitu dengan cara melakukan pengolahan dan klasifikasi data yang ada, kemudian dilakukan analisis atau kajian secara rasional dan obyektif dengan cara mendiskusikan/membandingkannya dengan teori atau norma-norma yang relevan dengan masalah penelitian.

\section{HASIL DAN PEMBAHASAN}

Berdasarkan hasil dan analisis data, maka mekanisme implementasi sidang penyelesaian sengketa informasi publik (ajudikasi non litigasi) di Komisi Informasi Provinsi Kalimantan Selatan, adalah sebagai berikut :

\section{Proses Tahapan di Badan Publik}

Sebelum pemohon mengajukan permohonan penyelesaian sengketa informasi publik ke Komisi Informasi, ada proses tahapan yang harus dilalui terlebih dahulu di badan publik, di mana pemohon mengajukan permohonan informasi publik. Proses tahapan tersebut adalah sebagai berikut:

\section{a. Prosedur/Mekanisme Memperoleh informasi di Badan Publik}

1) Pemohon informasi publik mengajukan permohonan permintaan informasi publik kepada badan publik, dalam hal ini pejabat pengelola informasi dan dokumentasi (PPID), baik langsung secara lisan atau melalui surat, email, atau via telepon. Pemohon tersebut bisa bersifat pribadi, kelompok orang atau badan hukum.

2) Pemohon harus menyebutkan nama, alamat, subyek dan bentuk 
informasi yang diminta, serta alasan memperoleh informasi tersebut.

3) PPID pada badan publik yang bersangkutan mencatat semua yang disebutkan oleh pemohon pada point 2) di atas, apabila permohonan diajukan secara lisan.

4) Pemohon harus meminta tanda bukti kepada PPID bahwa ia telah mengajukan permintaan informasi, disertai nomor pendaftaran permohonan permintaan informasi pada badan publik yang bersangkutan.

5) PPID wajib merespon/memberi jawaban secara tertulis atas permohonan permintaan informasi tersebut paling lambat 10 (sepuluh) hari kerja sejak diterimanya permohonan permintaan informasi tersebut. Badan publik yang bersangkutan dapat memperpanjang waktu untuk mengirimkan pemberitahuan jawaban/respon kepada pemohon paling lambat 7 (tujuh) hari kerja berikutnya dengan memberikan alasan secara tertulis.

\section{b. Prosedur/Mekanisme Pengajuan Keberatan kepada Badan Publik (PPID)}

1) Apabila permohonan informasi tidak direspon atau ditolak oleh PPID, maka pemohon dapat mengajukan keberatan secara tertulis kepada atasan PPID.

2) Atasan PPID harus memberikan tanggapan atau keputusan atas keberatan yang diajukan oleh pemohon tersebut. Apabila keputusan atasan PPID menguatkan putusan bawahannya (PPID), maka alasan tertulis harus disertakan bersama tanggapan/keputusannya tersebut.

3) Jika pemohon merasa puas atas tanggapan/putusan atasan PPID tersebut, maka keberatan/ sengketa antara pemohon dengan atasan PPID tersebut dianggap selesai.
4) Jika pemohon merasa tidak puas terhadap putusan atasan PPID tersebut, maka pemohon dapat mengajukan permohonan penyelesaian sengketa informasi publik kepada Komisi Informasi.

Pengajuan keberatan/sengketa informasi publik oleh pemohon ke Komisi Informasi disebabkan salah satu atau beberapa alasan sebagai berikut :

a. Penolakan atas permintaan informasi berdasarkan alasan pengecualian.

b. Tidak disediakannya informasi berkala.

c. Tidak ditanggapinya permintaan informasi.

d. Permintaan informasi ditanggapi tidak sebagaimana yang diminta.

e. Tidak dipenuhinya permintaan informasi.

f. Pengenaan biaya yang tidak wajar, dan/atau;

g. Penyampaian informasi yang melebihi waktu yang diatur oleh undang-undang.

\section{Proses Tahapan di Komisi Informasi}

Ada beberapa tahapan yang harus dilakukan dalam proses penyelesaian sengketa informasi publik di Komisi Informasi Informasi Provinsi Kalimantan Selatan. Tahapan-tahapan tersebut adalah sebagai berikut :

\section{a. Prosedur/Mekanisme Administrasi Penyelesaian Sengketa Informasi Publik (PSI) di Komisi Informasi Provinsi Kalimantan Selatan}

1) Pemohon mengajukan permohonan sengketa informasi publik secara tertulis atau lisan kepada Komisi Informasi paling lambat 14 (empat belas) hari kerja sejak diterimanya keputusan dari atasan PPID atau berakhirnya masa 30 (tigapuluh) hari kerja, jika atasan PPID tidak memberikan tanggapan/keputusan tertulis. 
2) Dalam waktu 14 (empat belas) hari kerja, sejak diterimanya penerimaan permohonan penyelesaian sengketa informasi (PSI), Komisi Informasi harus melakukan proses penyelesaian sengketa melalui mediasi dan/atau ajudikasi.

3) Proses PSI yang dilakukan Komisi Informasi melalui mediasi dan/atau ajudikasi tersebut diselesaikan paling lambat 100 hari kerja.

4) Jika pada tahap mediasi dihasilkan kesepakatan, maka ditetapkan dalam bentuk putusan Komisi informasi, dan sengketa dianggap selesai.

5) Putusan Komisi Informasi yang berasal dari keepakatan melalui mediasi, bersifat final dan mengikat.

6) Jika mediasi gagal, tidak ada kata sepakat, maka Komisi Informasi melanjutkan proses PSI melalui ajudikasi.

7) Jika pemohon dan termohon puas atasan putusan ajudikasi dari Komisi Informasi, maka sengketa dianggap selesai. Jika salah satu puhak atau para pihak merasa tidak puas, maka sengketa sengketa dapat dilanjutkan ke Pengadilan Negeri (PN) atau ke Pengadilan Tata Usaha Negara (PTUN).

\section{b. Prosedur/Mekanisme Pelaksanaan Sidang Ajudikasi di Komisi Informasi Provinsi Kalimantan Selatan}

Ada beberapa langkah yang harus dilakukan di dalam proses persidangan ajudikasi di Komisi informasi, yaitu sebagai berikut :

1) Ketua Majelis Komisioner membuka persidangan, menyatakan sidang dibuka dan terbuka untuk umum, ditandai dengan mengetukkan palu sebanyak 3 (tiga) kali.
2) Melalui panitera/panitera pengganti, Ketua Majelis Komisioner mempersilahkan para pihak menempati ruang sidang.

3) Ketua Majelis Komisioner memerintahkan panitera/panitera pengganti untuk membacakan tata tertib persidangan.

4) Jika kehadiran para pihak lengkap, maka Majelis Komisoner akan melakukan proses pemeriksaan awal.

5) Proses pemeriksaan awal :

a) Pemeriksaan kedudukan hukum (legal standing) pemohon yaitu melalui pemeriksaan terhadap identitas pemohon dan/atau kuasanya. Apakah sebagai perseorangan ; kelompok orang ; atau badan hukum

b) Pemeriksaan kedudukan hukum (legal standing) termohon, yaitu memeriksa identitas pemohon atau kuasanya.

c) Pemeriksaan terhadap batas waktu (daluarsa) pengajuan permohonan penyelesaian sengketa informasi publik.

d) Pemeriksaan terhadap kewenangan Komisi informasi, baik kewenangan absolut maupun kewenangan relatif.

e) Secara bergantian Majelis Komisioner dapat memerintahkan pemohon dan termohon untuk menyampaikan kronologis sengketa informasi

f) Majelis Komisioner menggali informasi guna memperjelas duduk sengketa informasi.

g) Majelis Komisioner memerintahkan untuk dilakukan mediasi.

h) Sidang di skor untuk dilakukan mediasi. Ketua Majelis Komisioner mengetuk palu 1 kali.

6) Ketua Majelis Komisioner membuka sidang lanjutan (yang di skor) dengan mengetuk palu 1 kali. 
7) Melalui pengganti, Komisioner memanggil menempati masing.

8)

ajelis komisioner mengkonfirmasi dan memastikan bahwa para pihak dan/atau kuasanya tetap sama dengan sidang yang terdahulu.

9) Majelis Komisioner menyampaikan kepada para pihak tentang hasil mediasi. Apabila mediasi berhasil, maka sengketa dianggap selesai, tetapi apabila mediasi gagal maka sidang ajudikasi akan dilanjutkan.

10) Ketua Majelis Komisioner membuka persidangan lanjutan (sidang pembuktian) dengan mengetukkan palu sebanyak 1 kali.

11) Majelis Komisioner melakukan pemeriksaan pembuktian, baik melalui pemeriksaan terbuka, tertutup, maupun pemeriksaa setempat.

12) Pemeriksaan terbuka dilakukan untuk memeriksa :
a) Keterangan pemohon atau kuasanya.
b) Keterangan termohon atau kuasanya
c) Surat-surat.
d) Keterangan saksi, apabila diperlukan.
e) Keterangan ahli, apabila diperlukan
f) Rangkaian data, keterangan,
perbuatan, keadaan, atau peristiwa yang berkesesuaian dengan alat-alat bukti lain yang dapat dijadikan petunjuk, apabila diperlukan, dan/atau

g) Kesimpulan dari para pihak.

13) Pemeriksaan tertutup dilakukan hanya oleh Majelis komisioner dan pihak termohon, untuk memeriksa dokumen-dokumen yang dianggap rahasia negara.
14) Pemeriksaan setempat dilakukan untuk memperoleh bukti dengan didampingi oleh panitera/panitera pengganti dan dapat didampingi oleh pemohon dan/atau termohon atas pertimbangan Majelis Komisioner.

15) Para pihak dapat mengajukan bukti surat yang sah disertai materai yang cukup dalam bentuk daftar surat kepada Majelis Komisioner melalui panitera/panitera pengganti.

16) Majelis Komisioner melanjutkan pemeriksaan saksi ataupun ahli, baik yang berasal dari pemohon, termohon, ataupun yang berasal dari Komisi Informasi.

17) Jika pemeriksaan dirasa cukup, Majelis Komisioner dapat memberikan kesempatan kepada para pihak untuk menyampaikan kesimpulan secara lisan maupun tertulis. Kesimpulan tertulis disampaikan kepada majelis Komisioner melalui panitera/panitera pengganti selambatnya 3 (tiga) hari kerja sebelum putusan dibacakan.

18) Ketua Majelis Komisioner menskor sidang dan mengumumkan jadwal sidang pembacaan putusan.

19) Sebelum sidang pembacaan putusan, Majelis Komisioner melakukan Rapat Musyawarah Majelis Komisioner secara tertutup dan bersifat rahasia untuk mengambil keputusan tentang sengketa informasi tersebut.

20) Putusan dibuat dalam 3 (tiga) berkas : asli untuk Komisi Informasi dan salinan asli masingmasing untuk para pihak.

21) Isi putusan sekurang-kurangnya memuat :

- Kepala putusan ;

- Identitas lengkap para pihak ;

- Duduk perkara yang sekurangkurangnya memuat : a) kronologi ; b) alasan permohonan ; c) petitum. 
- Alat bukti yang diajukan dan diperiksa ;

- Kesimpulan para pihak ;

- Pertimbangan hukum yang sekurang-kurangnya memuat :

a) Fakta hukum persidangan ;

b) Pendapat Majelis Komisioner ;

c) Kesimpulan ;

d) Amar putusan yang di dalamnya memuat pula mengenai jangka waktu pelaksanaan putusan ;

e) Hari dan tanggal musyawarak Majelis Komisioner ;

f) Hari dan tanggal putusan diucapkan/dibacakan, nama dan tanda tangan Majelis Komisioner yang memutus serta panitera/panitera pengganti yang mencatat persidangan; dan

g) Pendapat anggota Majelis Komisioner yang berbeda, apabila ada.

22) Pada sidang pembacaan putusan, Ketua Majelis Komisioner membuka sidang dengan mengetuk palu 1 kali.

23) Para pihak dapat tidak menghadiri sidang pembacaan putusan.

24) Pembacaan putusan dilakukan dalam sidang terbuka dan dibuka untuk umum.

25) Setelah putusan dibacakan oleh Majelis Komisioner, Ketua Majelis Komisioner memberitahukan hakhak para pihak berdasarkan Pasal 60 PERKI tentang PPISP.

26) Ketua Majelis Komisioner menyatakan sidang selesai dan ditutup dengan mengetukkan palu sebanyak 3 kali.

\section{KESIMPULAN}

Berdasarkan pada uraian hasil penelitian dan pembahasan tersebut di atas dapat ditarik beberapa kesimpulan :
1. Pelaksanaan penyelesaian sengketa informasi publik (ajudikasi nonlitigasi) di Komisi Informasi Provinsi Kalimantan Selatan, dilihat dari prosedural/mekanismenya, sudah sesuai dengan Undang-Undang Nomor 14 Tahun 2008 tentang Keterbukaan Informasi Publik dan Peraturan Komisi Informasi Nomor 1 Tahun 2014 tentang Prosedur Penyelesaian sengketa Informasi Publik.

2. Proses tahapan yang harus dilakukan dalam pelaksanaan penyelesaian sengketa informasi publik di Komisi Informasi Provinsi Kalimantan Selatan adalah, sbb :

a. Proses tahapan di badan publik, yaitu :

1) Pemohon mengajukan permohonan permintaan informasi publik kepada Pejabat Pengelola Informasi dan Dokumentasi (PPID).

2) Pemohon harus meminta tanda bukti tertulis kepada PPID bahwa ia telah mengajukan permohonan permintaan informasi publik.

3) Apabila permohonan permintaan informasi tersebut tidak direspon atau ditolak oleh PPID, maka pemohon dapat mengajukan keberatan secara tertulis kepada atasan PPID.

4) Apabila pemohon merasa tidak puas terhadap respon atau putusan atasan PPID, maka pemohon dapat mengajukan sengketa informasi ke Komisi Informasi.

b. Proses tahapan di Komisi Informasi, yaitu :

1) Pemohon mengajukan permohonan penyelesaian sengketa informasi ke Komisi informasi, dengan melengkapi persyaratan sesuai dengan ketentuan yang berlaku.

2) Komisi Informasi menerima, memeriksa, dan memutus sengketa informasi tersebut melalui mediasi dan/atau ajudikasi dengan cara memanggil dan mempertemukan pemohon dan termohon dalam sebuah persidangan.

3) Putusan sidang penyelesaian sengketa informasi tersebut paling 
lambat diselesaikan dalam waktu 100 (seratus) hari kerja.

\section{SARAN-SARAN}

1. Hendaknya dalam rangka meningkatkan profesionalitas dalam pelaksanaan mediasi dan/atau ajudikasi, para komisioner perlu mengikuti pelatihan mediasi dan/atau ajudikasi pada lembaga yang berkompeten.

2. Hendaknya dalam rangka meningkatkan profesionalitas dalam menjalankan tugastugas kepaniteraan, Sekretaris Komisi Informasi Provinsi Kalimantan Selatan perlu mengikuti pelatihan pada lembaga yang berkompeten.

3. Hendaknya dalam rangka menunjang kelancaran dan kualitas pelaksanaan mediasi dan/atau ajudikasi perlu dilengkapi sarana dan prasarana media dan/atau ajudikasi di Komisi Informasi Provinsi Kalimantan Selatan.

\section{REFERENSI}

---------, 2008, Undang-Undang Nomor 14 Tahun 2008 tentang Keterbukaan Informasi Publik, Jakarta: KI Pusat.

---------, 2013, Peraturan Komisi Informasi Nomor 1 Tahun 2013 tentang Prosedur Penyelesaian Sengketa Informasi Publik, Jakarta: KI Pusat.

Imron, Ali, 1996, Kebijakan Pendidikan di Indonesia, P3T IKIP Malang.

Islamy, M. Irfan, Kebijakan Publik (Modul), Jakarta: Universitas Terbuka.

Moeleong, Lexy J, 2006, Metodologi Penelitian Kualitatif, Bandung: Remaja Rosda Karya.

MPR RI, 2002, Undang-Undang Dasar RI Tahun 1945, Jakarta: Sekretariar Jenderal MPR RI.

Nawawi, Ismail, 2009, Public Policy (Analisis, Strategi, Advokasi, Teori dan Praktik), Surabaya: PNM.

Nugroho, Riant, 2011, Public Policy (Dinamika Kebijakan- Analisis Kebijakan-
Manajemen Kebijakan), Jakarta: PT. Elex Media Komputindo.

Rawita, Ino Sutisno, Kebijakan Pendidikan (teori, Implementasi, dan Monev), Yogyakarta Kurnia Kalam Semesta, Yogyakarta.

Setyodarmodjo, Soenarko, 1998, Kebijaksanaan Pemerintah, Cet. I, Surabaya: CV. Papyrus.

Sugiono, 2010, Metodologi Penelitian Administrasi, Bandung: Alpabeta.

Wahab, Solichin Abdul, Analisis Kebijaksanaan dari Formulasi ke Implementasi Kebijaksanaan Negara, Ed. I, Jakarta:. Bumi Aksara.

117 | Tamliha Harun | Mekanisme Implementasi ..... 